\title{
The Impact of Innovation Process on Financial Performance in Micro, Small, and Medium Enterprises Case Study of Medan City MSMEs Production Sector
}

\author{
$1^{\text {st }}$ Muhammad Andi Abdillah Triono ${ }^{1}, 2^{\text {nd }}$ Henry Iskandar $^{2}, 3^{\text {rd }}$ Armin Rahmansyah \\ Nasution ${ }^{3}, 4^{\text {th }}$ Sienny ${ }^{4}$ \\ $\left\{\right.$ andiabdillah@unimed.ac.id $\left.{ }^{1}\right\}$ \\ Faculty of Economics ${ }^{1,3,4}$, Faculty of Technical Engineering ${ }^{2}$, \\ Universitas Negeri Medan, Jl. Willem Iskandar Pasar V, Medan ${ }^{1,2,3,4}$
}

\begin{abstract}
In the current era of uncertainty, especially during the COVID-19 pandemic, there is pressure for business actors to innovate so that business processes can survive. This research sheds light on how the characteristics of micro, small, and medium enterprises can carry out the innovation process to affect the company's financial performance to survive. This study is a case study and exploratory on micro, small, and medium enterprises in 21 districts in Medan City. The target population of this study is 466 micro, small, and medium enterprise actors who are part of the production sector in Medan City and confirmed to be active and operate in 2020, which is identified by the Cooperative and Small Medium Office Medan City. The sampling method is by using a stratified random sampling method. A questionnaire instrument was used to obtain the primary data, and the secondary data was obtained from the cooperative and smallmedium office databases. The validity and reliability testing of research instruments are on 49 micro, small, and medium enterprises of Deli Serdang Regency MSMEs production sector. One hundred sixty-nine respondents returned the questionnaire with complete fields. SEM-PLS carries out data processing, and the model fit test is tested through the SRMR calculation, which confirms that the model is in the goodness of fit. Thus, this research empirically proves that the innovation process in the micro, small, and medium enterprises in the production sector of Medan City can explain financial performance characteristics.
\end{abstract}

Keywords: Innovation process- financial performance- micro small and medium enterprises- production sector.

\section{Introduction}

The concept of innovation has been widely discussed and analyzed from different perspectives: product innovation, process innovation, organizational innovation, marketing innovation, radical and incremental innovation, administration, and technology innovation [1]. The terminology of innovation is a new idea, method, or device, or generally defined as an introduction to something new [2]. According to Widya-Hasuti et al., [3], small businesses are constantly faced with innovating due to the scarcity of resources. Therefore, SMEs have always faced difficulty investing in technology and human resources with anticipating ecological impacts or integrating the business into social aspects, namely corporate social responsibility (CSR) as one of the business strategies to obtain tax relief. Based on 
observations on Google Scholar with the keyword "Indonesian SMEs innovation financial performance" from 2016 to 2020, only two relevant scientific articles have been identified discussing the innovation and financial performance of SMEs in Indonesia. Namely, a study conducted by Games \& Rendi [4] on 165 small business owners in Indonesia that negative investment is not a mediator between knowledge management, risk-taking, and the financial performance of MSMEs in Indonesia. However, negative innovation can be reduced through knowledge management and risk-taking. Furthermore, a study conducted by Ismanu \& Kusmintarti [5] on batik business actors in East Java, Indonesia, found that continuous innovation will improve the financial performance of small and medium batik entrepreneurs in East Java.

Various studies have proven that product and process innovation can improve small and medium enterprises [6]. Furthermore, the results of a study conducted by Haryati et al. [7] on SMEs in West Sumatra showed that process, product, and marketing innovation significantly affected the sustainability of SMEs' performance. Then, let us look at established companies such as pharmaceutical companies in Indonesia; the study conducted by Muharam et al. [8] proves that process innovation strongly influences financial performance. The relationship between financial performance and process innovation is significantly moderated by marketing innovation.

It is empirically proven that the ability to innovate in the context of SMEs leads to two research lines: research that examines the determination that shapes the ability of SMEs to innovate, and research that examines the consequences or impact of the ability of SMEs to innovate [9]. This study examines the impact of process innovation on the financial performance of Medan City MSMEs. Medan City is the Indonesian west gateway of economics from the Dutch East Indies colonial era, multicultural, and the third-largest city after Jakarta and Surabaya. Furthermore, this study uses five indicators as determinants of process innovation by MSMEs in Medan City according to the construct built by Shashi et al. [1], namely: elimination of non-added value in the delivery process, speed logistics delivery, improvements to the technical quality of the production process, variable cost reductions, and elimination of non-added value in the production process.

\section{Theeory}

\subsection{Company Financial Performance (Firm Financial Performance)}

Several studies focus on financial performance because financial performance reflects the company's success in realizing the company's plans and operations in numbers [10]. Furthermore, financial performance is a sign of financial stability (financial stability) or a sign of a business's financial health (financial health). It serves to measure subjectively the extent to which the company can use its assets to generate income [11, 12]. Then, based on the results of a study conducted by Taouab \& Issuer [13,p.96] in mind that financial performance has a reciprocal relationship(recursive)with competitive competitiveness, and the competitiveness of the competition has a reciprocal relationship (recursive) and competitiveness, efficiency increase(efficiency), and effectiveness(effectivity). Furthermore, IGI Global Publisher [11] uses financial ratios to measure financial performance depending on the type of company or business sector; for example, financial companies should use ratio levels in stock prices, cash flow, income, and operating income. 
In contrast, the ratios that should be used in measuring financial performance are total unit sales, asset returns, and inventory turnover rates in manufacturing companies. Shashi et al. [1] built five indicators as determinants in measuring financial performance: return on investment, return on assets, sales growth, and the total operating cost. This study defines financial performance as a subjective measure in assessing the assets owned to generate income (cash inflow).

\subsection{Innovation}

In the Merriam-Webster dictionary [2] that innovation is a noun that is defined as an idea, method, or tool that is new or an introduction to something new. In this case, innovation (innovation) and invention (invention) are generally defined as synonyms, but there is a fundamental difference between innovation and invention. Where the definition of the invention (invention) is something that exists and has never existed in the past, while innovation (invention) is something new due to a change from the previous form [2, 14], in this study will focus on process innovation (process innovation) according to the construct built by Shashi, et al., [1]. Thus, the concept of process innovation in this study is all efforts in efficiency and effectiveness actions within the company.

In this case, this research study focuses on the financial performance of Medan City MSMEs by considering the background of the problem, then the formulation of the research problem is: Does the process innovation carried out by Medan City MSME actors affect the financial performance of MSMEs in Medan City?

So, with arguments from the background of the problem and the theoretical basis, the hypotheses of this research are: hypotheses: MSME actors in Medan City carry out an effect of process innovation on its financial performance

\section{Methods}

This research is explorative with descriptive, inferential properties. Primary and secondary data were used in this study. Thus, the research instrument in the form of a questionnaire was formed according to the construction built by Shashi et al., [1] and Hofer et al., [15]. Testing the validity and reliability of the research instrument was carried out in 23 districts in Deli Serdang Regency from June 10th, 2020, to the end of June 2020, with 49 respondents from 100 targeted respondents, namely business owners.

\subsection{Research Location}

This research was conducted in 21 districts of Medan City. With a time frame from August 1th 2020, to October 25th, 2021.

\subsection{Data Collection}

The research population is all MSMEs in the City of Medan in the Production Sector fostered and recorded by the Department of Cooperatives and MSMEs in Medan City in 2020 with 466 business actors. The sample size technique is a stratified random sampling strategy to represent all micro, small and medium enterprises. In addition, the minimum sample size must also be met based on a statistical power analysis of 80 percent, according to Cohen's (1992) 
table [16, p. 26]. Thus, exogenous variables: innovation process has five indicators, the minimum number of samples required are as many as 45 respondents to obtain 80 percent in detecting R2 of 0.25 with 5 percent error probability. The endogenous variable of financial performance has four indicator variables, so the minimum required respondents are as many as 41 respondents to obtain 80 percent in detecting $\mathrm{R} 2$ of 0.25 with 5 percent error probability. The research instrument in a questionnaire was used, with the target respondents being business owners. Furthermore, the distribution of the questionnaires was carried out by sending them via mail and direct telephone as a reminder after two weeks of delivery. In this case, 169 respondents returned and filled in completely.

\subsection{Variabels}

This study consists of one endogenous variable: financial performance with four indicator variables and one exogenous variable, process innovation, with five indicators. The research variables can be seen based on the operational research table as follows.

Table 1. Research operational.

\begin{tabular}{|c|c|c|c|c|c|c|}
\hline No. & Variable & Symbol & $\begin{array}{c}\text { Type of } \\
\text { Data }\end{array}$ & Definition & Variable of Manifest & Scale \\
\hline 1 & $\begin{array}{l}\text { Innovation } \\
\text { on Process }\end{array}$ & $\xi$ & Exogenous & $\begin{array}{l}\text { All efforts in } \\
\text { efficiency and } \\
\text { effectiveness } \\
\text { actions that } \\
\text { occur within } \\
\text { the company. }\end{array}$ & 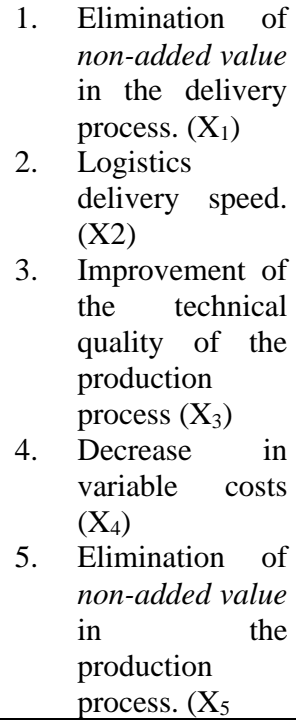 & $\begin{array}{c}\text { Linkert } \\
\text { (Interval) }\end{array}$ \\
\hline 2 & $\begin{array}{c}\text { Financial } \\
\text { Performance }\end{array}$ & $\eta$ & Endogenous & $\begin{array}{l}\text { A subjective } \\
\text { measure in } \\
\text { assessing the } \\
\text { ability of } \\
\text { assets owned } \\
\text { to generate } \\
\text { income (Cash } \\
\text { inflow) }\end{array}$ & $\begin{array}{ll}\text { 1. } & \text { Return on } \\
\text { Investment }\left(\mathrm{Y}_{1}\right) \\
\text { 2. }\end{array} \begin{array}{l}\text { Return on Assets } \\
\left(\mathrm{Y}_{2}\right) \\
\text { 3. }\end{array}$ & $\begin{array}{c}\text { Linkert } \\
\text { (Interval) }\end{array}$ \\
\hline
\end{tabular}

\section{4 The Model Construct (Research Model)}


The structure of this research model can be described as follows.

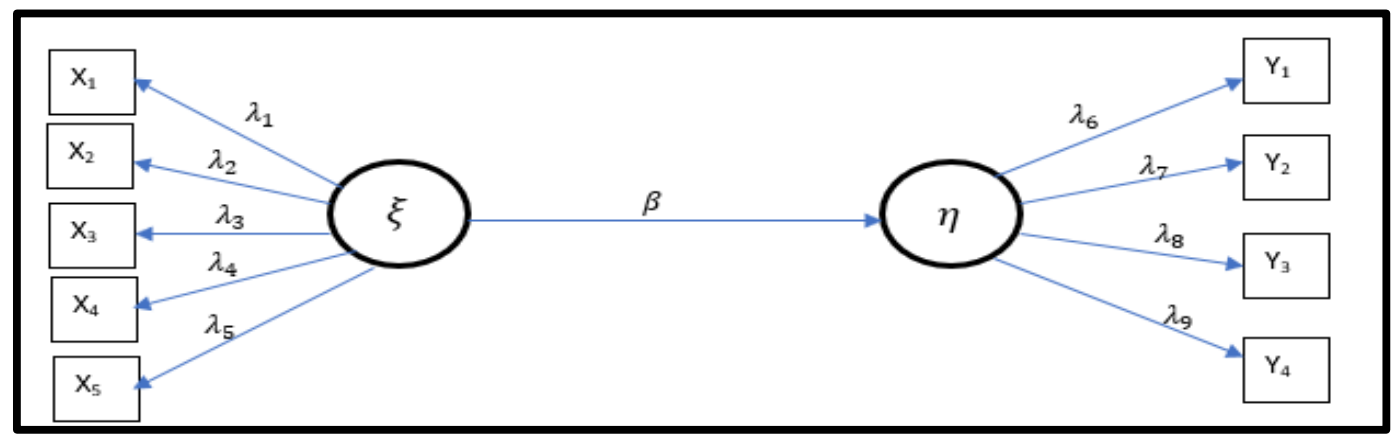

Fig. 1. Research Model Construct

\subsection{Data Analysis}

Analysis was carried out using the Simultaneous Equation Modeling - Partial Least Square method, where measurement models were carried out, both inner and outer models with a significance level of 0.10 . Testing the direction of the indicator arrows is carried out by testing the correlation between indicator variables in each construct, whether reflective or formative. In this case, SmartPLS 3.0 is used to determine the acceptance or rejection of statistical hypotheses that the PLS Algorithm and Bootstrapping have set both. After knowing the significance of the inner and outer models, the next step is to know the model's fit by looking at the level of Standardized Root Mean Square Residual (SRMR).

\section{Result and Discussion}

\subsection{Outer Model Analysis}

Based on the calculation results of the PLS Algorithm, it is known that all outer models are declared valid above 0.70 , except for Y1, which is Return on Investment. This condition indicates that the five innovation process indicators are empirically able to explain the characteristics of the innovation process in MSMEs in Medan City. Then, of the four financial performance indicators, three of them can explain financial performance.

Table 2. Calculation result of outer model.

\begin{tabular}{|c|c|c|}
\hline & $\begin{array}{c}\text { Financial } \\
\text { Performance }\end{array}$ & $\begin{array}{c}\text { Innovation } \\
\text { Process }\end{array}$ \\
\hline X1 & & $\mathbf{0 . 8 5 4}$ \\
\hline Y2 & $\mathbf{0 . 8 7 7}$ & \\
\hline X2 & & $\mathbf{0 . 8 7 1}$ \\
\hline Y3 & $\mathbf{0 . 8 6 8}$ & \\
\hline Y4 & $\mathbf{0 . 8 5 0}$ & \\
\hline
\end{tabular}




\begin{tabular}{|c|c|c|}
\hline & $\begin{array}{c}\text { Financial } \\
\text { Performance }\end{array}$ & $\begin{array}{c}\text { Innovation } \\
\text { Process }\end{array}$ \\
\hline X3 & & $\mathbf{0 . 8 3 5}$ \\
\hline X4 & & $\mathbf{0 . 8 5 0}$ \\
\hline X5 & & $\mathbf{0 . 8 9 2}$ \\
\hline
\end{tabular}

\subsection{Inner Model Analysis}

Based on the results of the Bootstrapping calculation, it is known that the innovation process variable can significantly affect the financial performance of Medan City MSMEs with an influence coefficient level of 0.742 or 74.2 percent able to affect financial performance. This number is shown in the following table of bootstrapping - path coefficient results

Table 3. Path coefficient

\begin{tabular}{|l|l|l|r|r|r|}
\hline & $\begin{array}{l}\text { Original } \\
\text { Sample (O) }\end{array}$ & $\begin{array}{l}\text { Sample Mean } \\
\text { (M) }\end{array}$ & $\begin{array}{l}\text { Standard } \\
\text { Deviation } \\
\text { (STDEV) }\end{array}$ & $\begin{array}{l}\text { T Statistics } \\
(\mid \text { O/STDEV|) }\end{array}$ & P Values \\
\hline $\begin{array}{l}\text { Inovation } \\
\begin{array}{l}\text { Process -> } \\
\text { Financial } \\
\text { Performance }\end{array}\end{array}$ & 0.742 & 0.742 & 0.042 & 17.499 & $\mathbf{0 . 0 0 0}$ \\
\hline
\end{tabular}

\subsection{Model Fit}

The fit model produced in this study shows a value below 0.08 , namely 0.056 , which indicates that the model has been significantly confirmed fit. The calculation of the model fit can be seen in the following model fit table:

Table 4. Model Fit.

\begin{tabular}{|l|c|c|}
\hline & Saturated Model & $\begin{array}{c}\text { Estimated } \\
\text { Model }\end{array}$ \\
\hline SRMR & 0.056 & 0.056 \\
\hline d_ULS & 0.113 & 0.113 \\
\hline d_G & 0.075 & 0.075 \\
\hline Chi-Square & 75.284 & 75.284 \\
\hline NFI & 0.915 & 0.915 \\
\hline
\end{tabular}

The results show that empirically the research hypothesis has been accepted, namely that there is an innovation process that significantly affects the financial performance of Medan City SMEs with an influence value of 74.2 percent. In this case, the characteristics of the innovation process of SMEs in Medan City are:

a. considering the elimination of non-added value in the delivery process

b. focus on speed logistics delivery, 
c. improvements on the technical quality of the production process,

d. concern on variable cost reductions, and

e. focusing on the elimination of non-added value in the production process.

Then, the financial performance of Medan City SMEs has the characteristics of maintaining the asset return ratio, focusing on increasing sales growth, focusing on the total operating costs owned. The results of this study are similar to the results of studies conducted by Shashi et al., [1], Hofer et al., [15], and Haryati et al., [7].

\section{Conclusion}

This study shows that the innovation process variable for SMEs in Medan City significantly influences financial performance. This empirical visual can be a way for researchers and business practitioners to improve financial performance that the innovation process factor is significant for SMEs, especially in the city of Medan.

\section{References}

[1] Shashi PC, Cerchione R, Singh R. The Impact of leanness and innovativeness on environmental and financial performance: Insights from Indian SMEs. International Journal of Production Economics. 2019; 212: 111-124.

[2] Merriam-Webster. Innovation. [Online]. Available: https://www.merriamwebster.com/dictionary/innovation. [Accessed 10 May 2020].

[3] Hasuti WA, Mardani A, Streimikiene D, Sharifara A, Cavallaro F. The Role of Process Innovation between Firm-Specific Capabilities and Sustainable Innovation in SMEs: Empirical Evidence from Indonesia. Sustainability. 2018; 10(7).

[4] Games D, Rendi RP. The effects of knowledge management and risk taking on SME financial performance in creative industries in an emerging market: the mediating effect of innovation outcomes. Journal of Global Entrepreneurship Research. 2019; (9).

[5] Ismanu S, Kusmintarti A. Innovation and Firm Performance of Small and Medium Enterprises. Review of Integrative Business and Economics Research. 2019; 8(2): 312-323.

[6] Saleem H, LI YZ, Ali A, Mehreen, Mansoor MS. An empirical investigation on how big data analytics influence China SMEs performance: do product and process innovation matter?. ASIA PACIFIC BUSINESS REVIEW. 2020.

[7] Haryati R, Yasri Y, Aimon H, Darwin M. Development Of Small, Micro Enterprises Based (Smes) On Innovation And Environmental Sustainable Development In West Sumatera. International Journal of Entrepreneurship. 2021; 25(4).

[8] Muhara H, Andria F, Tosida ET. Effect of Process Innovation and Market Innovation on Financial Performance with Moderating Role of Disruptive Technology. Systematic Review Pharmacy. 2020; 11(1):223-232.

[9] Saunila M. Innovation capability in SMEs: A systematic review of the literature. Journal of Innovation \& Knowledge. 200; 260-265. 
[10] Jum'a L, Zimon D, Ikram M. A Relationship bertween Supply Chain Practices, Environmental Sustainability and Financial Performance: Evidence from Manufacturing Companies in Jordan. Sustainability. 2021.

[11] IGI Global Publisher. What is Firm Performance. [Online]. Available: https://www.igiglobal.com/dictionary/accounting-standards-in-the-us-banking-industry-during-the-financialcrisis/51090. [Accessed 8 May 2020].

[12] Kenton W. Financial Performance. [Online]. Available: https://www.investopedia.com/terms/f/financialperformance.asp. [Accessed 9 May 2020].

[13] Taouab O, Issor Z. Firm Performance. Definition and Measurement Model. European Scientific Journal. 2019; 15(1): 93-106.

[14] Cambridge Dictionary. Invention.[Online]. Available: https://dictionary.cambridge.org/dictionary/english/invention. [Accessed 12 Mayv2020].

[15] Hofer C, Eroglu C, Hofer AR. The effect of lean production on financialperformance: The mediating role of inventory leanness. International Journal of Production Economics. 2012; 138(2);242-253.

[16] Joseph J, Hair F, Hult GTM, Ringle CM, Sarstedt M. A Primer On Partial Least Squares Structural Equation Modelling (PLS-SEM), Singapore: SAGE Publications Ltd; 2014. 